\title{
Effect of simulated rain on the efficiency of fungicides in potato late blight and early blight control
}

\section{Efeito de chuva simulada sobre a eficiência de fungicidas no controle da requeima e pinta preta da batata}

\author{
Jesus Guerino Töfoli ${ }^{1 *}$; Ricardo José Domingues ${ }^{1}$; \\ Paulo César Tavares de Melo²; Josiane Takassaki Ferrari ${ }^{1}$
}

\begin{abstract}
Rainfastness of fungicides used in the control of late blight (Phytophthora infestans) and early blight (Alternaria solani) of potato was evaluated under green house and laboratory conditions. 'Agata' and 'Monalisa' plants treated with fungicides against both diseases were subjected to $20 \mathrm{~mm}$ controlled rain simulation for $6 \mathrm{~min}$ at $30 \mathrm{~min}, 1,2$, and $4 \mathrm{~h}$ after application. Once all leaves had dried, foliar discs were transferred to Petri dishes and inoculated with the respective pathogens. The plates were then incubated in a BOD chamber for a 12 -h photoperiod at $18^{\circ} \mathrm{C}$ and $25^{\circ} \mathrm{C}$, respectively. Disease severity was evaluated by determining the area (\%) of the foliar discs affected by disease on 5 and 7 days postinoculation. The results suggest that systemic or inherent tenacity fungicides were less influenced by the simulated rain as compared to contact fungicides. An increase in drying time promoted higher control levels of both diseases, indicating a better retention and absorption of the tested fungicides.
\end{abstract}

Key words: Phytophthora infestans, Alternaria solani, Solanum tuberosum L., tenacity, rainfastness

\section{Resumo}

A resistência de fungicidas à chuva no controle da requeima (Phytophthora infestans) e pinta preta (Alternaria solani) da batata foi avaliada em condições de casa-se vegetação e laboratório. Plantas de batata das cultivares Agata e Monalisa tratadas com fungicidas indicados para as duas doenças foram submetidas à chuva controlada de $20 \mathrm{~mm}$ durante 6 minutos aos 30 minutos, 1,2 e 4 horas após a pulverização. Após a secagem das plantas, discos foliares foram coletados e transferidos para placas de Petri e inoculados com os patógenos. Em seguida as placas foram incubadas em câmara BOD a $18^{\circ} \mathrm{C}$ para $P$. infestans e $25^{\circ} \mathrm{C}$ para A. solani, sob fotoperíodo de 12 horas. A severidade foi avaliada através da porcentagem da área do disco afetada pelas doenças aos 5 e 7 dias após a inoculação, respectivamente. Os resultados obtidos permitiram concluir que os fungicidas sistêmicos, translaminares ou com tenacidade inerente foram menos afetados pela chuva simulada quando comparados aos fungicidas de contato. O aumento do tempo de secagem promoveu maiores níveis de controle da requeima e pinta preta, evidenciando uma maior retenção ou absorção dos produtos testados.

Palavras-chave: Phytophthora infestans, Alternaria solani, Solanum tuberosum L., tenacidade, resistência à chuva

\footnotetext{
${ }^{1}$ Eng $^{\text {os }}$ Agros , Pesquisadores, APTA - Agência Paulista de Tecnologia dos Agronegócios, Instituto Biológico, Centro de Pesquisa e Desenvolvimento de Sanidade Vegetal, CPDSV, São Paulo, SP, Brasil. E-mail: tofoli@biologico.sp.gov.br; domingues@, biologico.sp.gov.br; takassaki@biologico.sp.gov.br

${ }^{2}$ Eng $^{\circ}$ Agr ${ }^{\circ}$, Prof. Associado, Universidade de São Paulo, USP, ESALQ, Piracicaba, SP, Brasil. E-mail: paulomelo@usp.br

* Author for correspondence
} 


\section{Introduction}

Late blight, caused by Phytophthora infestans, and early blight caused by Alternaria solani, are among the most important and common diseases affecting potato crops in Brazil and other regions worldwide (DIAS; IAMAUTI, 2005; TÖFOLI et al., 2012).

Due to the high destructive potential of these diseases, the systematic and targeted use of fungicides in integrated production systems is necessary (STEVENSON; KIRK; ATALLAH, 2008; TÖFOLI et al., 2013). In addition to providing local or systemic protection for the plant, the efficacy of a fungicide is closely related to the ability of its active ingredient to resist physical, chemical, or biological degradation caused by external factors such as solar radiation, heat, wind erosion, and wash-off from rain or irrigation water (SCHILDER, 2010).

Rain is one of the main factors that can affect the efficacy of fungicides. The ability of a fungicide to control phytopathogens is directly related to the amount of product that adheres to, or is absorbed by, the plant, as well as the concentration that remains active in the plant after rain exposure $\mathrm{RICH}$, 1954, HUNSCHE et al., 2007). Rain can affect the activity of a fungicide by causing its dilution, redistribution, or physical removal from the site of application (THACKER; YOUNG, 1999). The factors that may affect this interaction include quantity, intensity, and frequency of precipitation (CABRAS et al., 2001; FIFE; NOKES, 2002); time taken for the deposits to dry (SCHEPERS, 1996; DUARTE, 2008); product formulation (KUDSK; MATHIASSEN; KIRKNEL, 1991; TÖFOLI et al., 2006); applied dose (SCHILDER, 2010); use of adjuvants (KUDSK; MATHIASSEN; KIRKNEL, 1991; GREEN, 2001), and the nature of the treated leaf surface (REYNOLDS; REILLY; HOTCHKISS, 1994; DEBORTOLI, 2008).

Moreover, the impact of rain on the efficacy of fungicides is also directly related to the systemicity and tenacity of fungicides (BRUGGEN et al., 1987;
EVENHUIS et al., 1998). As contact fungicides form a protective film over the treated surface, they are more susceptible to the negative effects of rain, dew, and humidity. While studying the retention of mancozeb and chlorothalonil on muskmelon, Suheri and Latin (1991) found that the activity of both fungicides were comparable under dry conditions; however, mancozeb showed lower tenacity and efficacy in a wet environment. According to Schilder (2010), systemic fungicides tend to be less vulnerable to wash-off, since they are absorbed and redistributed by the plant. Santos et al. (2002) observed that exposure to $20 \mathrm{~mm}$ of simulated rainfall, $15 \mathrm{~min}$ after each application, did not interfere with the efficacy of cyproconazole and tetraconazole in the control of coffee leaf rust. However, it is well known that shorter duration between pulverization and exposure to rain increase the chance of fungicides being washed off (OLIVEIRA, 2009).

A few studies have investigated the effect of rain and irrigation water on the efficacy of fungicides used to control late blight of potato. Schepers (1996) investigated the effect of $10 \mathrm{~mm}$ simulated rain on fungicide deposits in potato plants and observed that precipitation occurring $4 \mathrm{~h}$ after application (HAA) of fungicide showed a greater effect on the efficacy of maneb than that of fluazinam. In certain cases, rain increased the efficacy of fluazinam, likely due to a redistribution of deposits on the leaf surface.

There are limited studies about the effect of precipitation on the efficacy of fungicides under environmental conditions within Brazil. Oliveira, Santos and Guzzo (2002), Santos et al. (2002), and Töfoli, et al. (2002) investigated the impact of simulated rain on the efficacy of copper fungicides, triazoles, and strobilurins, respectively, used in the control of coffee leaf rust (Hemileia vastatrix). Debortoli (2008) found that simulated rain had different effects on the efficacy of the fungicides azoxystrobin + cyproconazole, pyraclostrobin + cyproconazole, and tebuconazole used to control Asian soybean rust (Phakopsora pachyrhizi) in 
seven soybean cultivars. Duarte (2008) investigated the effect of simulated rain on contact fungicides in potato and tomato plants and showed that the drying time of the deposits plays a key role in the efficacy of these fungicides.

The rain not only limits the effective control of fungicides, but it also promotes the occurrence of epidemics of early and late blight of potato, as it leads to increased humidity and easier dispersion of reproductive structures. Therefore, it is essential to understand how fungicide control is affected by rain in order to establish guidelines for their repeated application. The purpose of this study was to evaluate the impact of different intervals of intense simulated rain on the efficacy of fungicides with different systemicity levels used in the control of early and late blight of potato.

\section{Materials and Methods}

Two experiments were performed under greenhouse and laboratory conditions following the protocol proposed by Schepers, Nielsen, and Duvauchelle (2004).

Rain simulation was performed using an experimental prototype designed by Santos (2000). The quantity and intensity of precipitation was adjusted to obtain $20 \mathrm{~mm}$ of precipitation for $6 \mathrm{~min}$ at $30 \mathrm{~min}, 1,2$, and 4 hours after application (HAA). A bioassay was performed after $24 \mathrm{~h}$ by collecting $1.5 \mathrm{~cm}$ diameter leaf discs from marked leaves, which were subsequently transferred to Petri dishes $\left(\right.$ Pyrex $\left.^{\circledR}\right)$ and covered with filter paper moistened with distilled water. The discs were then inoculated with specific pathogens (experiments 1 and 2) and incubated in a BOD type oven. A completely randomized experimental design was adopted with six repetitions. Each repetition comprised a plate containing 10 leaf discs.

For the two experiments, the potato plants were grown in plastic pots (PT 15) containing pine bark substrate, expanded vermiculite, and processed turf, which were enriched with nutrients especially formulated for Solanaceae plants. Two sprouted tubercles were planted in each pot originating from plants containing 2-3 stems. Care was taken to avoid lodging. Fungicides were applied using a costal pulverizer that was pressurized with $\mathrm{CO}_{2}$, fitted with a single nozzle (conical nozzle model Spraying Systems Co. TXKV26), and calibrated to a constant pressure of 3 Bar, an application volume of $300 \mathrm{~L} \mathrm{ha}^{-1}$, with an approximate distance of $0.5 \mathrm{~m}$ between the tip of the nozzle and the target.

\section{Experiment 1. Effect of simulated rain on the efficacy} of fungicides used in the control of potato late blight

Potato plants ('Agata'), approximately $25 \mathrm{~cm}$ high, were treated with the following fungicides ( $\%$ active ingredient $-\mathrm{Kg}$ or $\mathrm{L}$ of the formulated product - f.p ha-1): pyraclostrobin + metiram $(5+$ $50-1.5)$, dimethomorph + ametoctradin $(22.5+$ $30-1.0)$, dimethomorph + mancozeb $(50+80-$ $0.45+3.0)$, dimethomorph + chlorothalonil $(50+$ $82.5-0.45+1.5)$, cymoxanil + mancozeb $(8+64$ $-2.0)$, cymoxanil + zoxamide (31.1 and $31.1-0.4)$, mefenoxam + mancozeb $(4+64-2.5)$, mefenoxam + chlorothalonil $(6.75+67.5-1.5)$, mandipropamid (25 - 0.4), mandipropamid + chlorothalonil $(4+$ $40-2.0)$, famoxadone + cymoxanil $(22.5+33-$ $0.6)$, fenamidone $(50-0.3)$, propamocarb (72.2 $-1.25)$, fenamidone + propamocarb $(7.5+37.5$ $-2.0)$, fluopicolide + propamocarb $(6.25+62.5-$ $2.0)$, benthiavalicarb + fluazinam $(10+25-0.7)$, ametoctradin + metiram $(12+44-2.0)$, cyazofamid $(40-0.25)$, fluazinam $(50-1.0)$, chlorothalonil $(82.5-1.5)$, mancozeb NT $(80-3.0)$, or mancozeb PM $(80-3.0)$.

After application of the relevant fungicide, plants were subjected to controlled rain at different intervals followed by sampling of leaf discs.

The discs were inoculated with $10 \mu \mathrm{L}$ of a suspension containing $10^{5}$ sporangia of $P$. infestans per milliliter, and the plates were incubated at $18^{\circ} \mathrm{C} \pm$ $1{ }^{\circ} \mathrm{C}$ for a 12 -h photoperiod. The severity of late blight 
disease was evaluated 6 days after inoculation (DAI) using a 1-5 scoring system, where: $1=$ absence of symptoms; $2=$ traces to $12.5 \% ; 3=12.6 \%-25 \%$; $4=25.1 \%-50 \%$, and $5=$ greater than $50 \%$ of the leaf disc was damaged. A factorial design with a total of 23 treatments (22 fungicides and one control) and five intervals between application and rain simulation (no rain, $30 \mathrm{~min}$, and 1, 2, and 4 HAA) were used to perform statistical analysis. Tukey's test was used to compare the results at 5\% probability.

Experiment 2. Effect of simulated rain on the efficacy of fungicides used in the control of potato early blight

Potato plants ('Monalisa'), approximately $27-\mathrm{cm}$ high, were treated with the following fungicides ( $\%$ active ingredient $-\mathrm{Kg}$ or L of the formulated product - f.p. ha $\left.{ }^{-1}\right)$ : picoxystrobin $(25-0.25)$, azoxystrobin $(50-0.08)$, azoxystrobin + difenoconazole $(20+$ $12.5-0.75)$, pyraclostrobin + metiram $(5+50-$ $1.5)$, pyraclostrobin + metconazole $(13+8-0.6)$, trifloxystrobin + tebuconazole $(20+10-0.75)$, tebuconazole $(20-1.0)$, metconazole $(0.9-1.0)$, difenoconazole $(25-0.3)$, flutriafol $(12.5-0.75)$, boscalid $(50-0.10)$, boscalid + pyraclostrobin $(20$ $+10-0.25)$, cyprodinil $(75-0.25)$, pyrimethanil $(30-1.0)$, iprodione + pyrimethanil $(15+25-$ $0.3+0.5)$, famoxadone + mancozeb $(6.25+62.5$ $-1.2)$, iprodione $(50-1.0)$, fluazinam $(50-1.0)$, chlorothalonil $(82.5-1.5)$, mancozeb NT (80 $3.0)$, or mancozeb PM $(80-3.0)$.

After application of the relevant fungicide, plants were subjected to controlled rain at different intervals; thereafter, the leaf discs were sampled.

The discs were inoculated with $10 \mu \mathrm{L}$ of a suspension containing $10^{4}$ conidia of $A$. solani per milliliter, and the plates were incubated at $25^{\circ} \mathrm{C}$ for a $12 \mathrm{~h}$ photoperiod. The severity of the early blight disease was evaluated 7 days after inoculation (DAI) using a 1-6 scoring system, where: $1=$ absence of symptoms; $2=$ traces to $2.5 \% ; 3=2.6 \%-12 \% ; 4$ $=12.1 \%-25 \% ; 5=25.1 \%-50 \%$; and $6=$ greater than $50 \%$ of the leaf disc was damaged. A completely randomized experimental design was adopted with six repetitions. A plate containing 10 leaf discs represented each repetition. A factorial design with a total of 21 treatments (20 fungicides and one control) and five intervals (no rain, $30 \mathrm{~min}$, and 1, 2, and 4 HAA) was used for the statistical analysis. Tukey's test was used to compare the means at $5 \%$ probability.

\section{Results and Discussion}

In experiment 1 , all fungicides were effective at controlling late blight in potato plants in the absence of simulated rain. Traces of the disease were only observed in plants treated with mancozeb and chlorothalonil (Table 1 and Figure 1).

When rain was simulated at $30 \mathrm{~min}$ and $1 \mathrm{HAA}$, the fungicides dimethomorph + ametoctradin, dimethomorph + chlorothalonil, mefenoxam + mancozeb, mefenoxam + chlorothalonil, mandipropamid, mandipropamid + chlorothalonil, famoxadone + cymoxanil, ametoctradin + metiram, propamocarb, fenamidone + propamocarb, fluopicolide + propamocarb, cymoxanil + zoxamide, and benthiavalicarb + fluazinam were found to be the most effective in late blight control. The fungicides cyazofamid, pyraclostrobin + metiram, fenamidone, and fluazinam showed intermediate efficacy, whereas dimethomorph + mancozeb, cymoxanil + mancozeb, mancozeb NT, and chlorothalonil were the least effective. No difference was observed between the mancozeb treated patches and the control patch. Cyazofamid showed intermediate efficacy at 30-min after application; however, it was as effective as the best treatment observed at the 1 HAA interval.

When rain was simulated at 2 and 4 HAA, the same level of blight control was observed for most of the treatments. The patches treated with dimethomorph + mancozeb, cymoxanil + mancozeb, and fenamidone showed a significant increase in disease control at the indicated intervals. Mancozeb PM demonstrated greater efficacy at 4 HAA only. 
Figure 1. Severity of late blight (Phytophthora infestans) in potato plants ('Agata') treated with fungicides with and without exposure to simulated rain $(20 \mathrm{~mm})$ at $30 \mathrm{~min}, 1,2$, and $4 \mathrm{~h}$ after application.

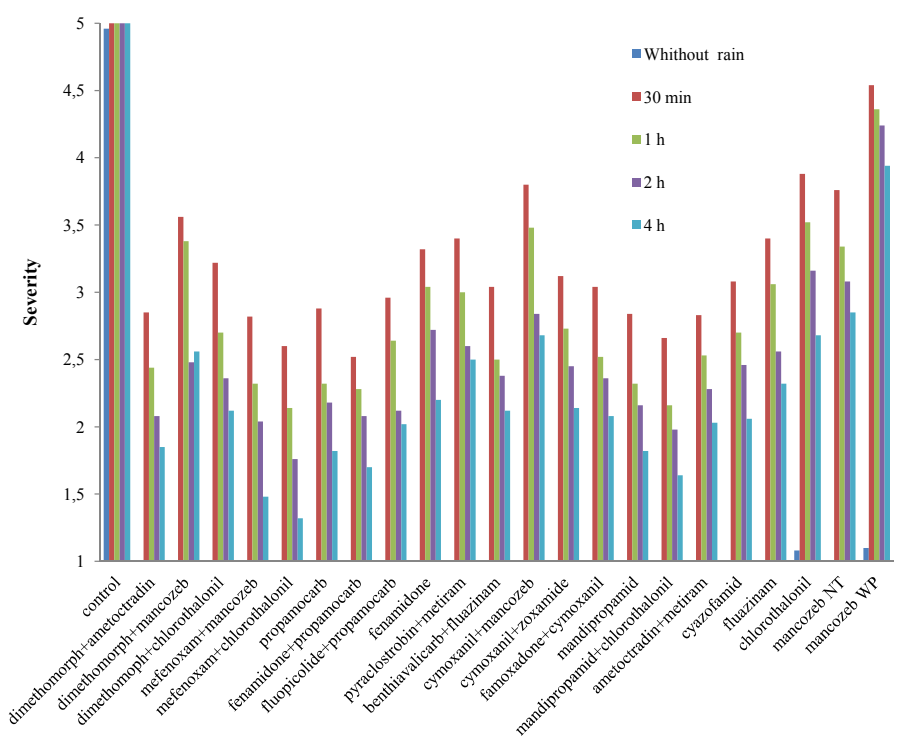

Source: Elaboration of the authors.

Table 1. Severity of late blight (Phytophthora infestans) in potato plants ('Agata') treated with fungicides and subjected to controlled rain $(20 \mathrm{~mm})$ at $30 \mathrm{~min}, 1,2$, and $4 \mathrm{~h}$ after application.

\begin{tabular}{llllll}
\hline \multirow{2}{*}{ Treatment } & \multicolumn{5}{c}{ Time interval for subjecting plants to controlled rain after fungicide application } \\
& No rain & $30 \mathrm{~min}$ & $1 \mathrm{~h}$ & $2 \mathrm{~h}$ & $4 \mathrm{~h}$ \\
\hline control & $4.96 \mathrm{aA} *$ & $5.00 \mathrm{aA}$ & $5.00 \mathrm{aA}$ & $5.00 \mathrm{aA}$ & $5.00 \mathrm{aA}$ \\
dimethomorph + ametoctradin & $1.00 \mathrm{bC}$ & $2.85 \mathrm{defA}$ & $2.44 \mathrm{efB}$ & $2.08 \mathrm{fgB}$ & $1.85 \mathrm{fghiB}$ \\
dimethomorph + mancozeb & $1.00 \mathrm{bC}$ & $3.56 \mathrm{bcdA}$ & $3.38 \mathrm{bcA}$ & $2.48 \mathrm{defB}$ & $2.56 \mathrm{cdeB}$ \\
dimethomorph + chlorothalonil & $1.00 \mathrm{bD}$ & $3.22 \mathrm{cdefA}$ & $2.70 \mathrm{defgB}$ & $2.36 \mathrm{efgBC}$ & $2.12 \mathrm{defghC}$ \\
mefenoxam + mancozeb & $1.00 \mathrm{bC}$ & $2.82 \mathrm{efA}$ & $2.32 \mathrm{fgB}$ & $2.04 \mathrm{fgB}$ & $1.48 \mathrm{hiC}$ \\
mefenoxam + chlorothalonil & $1.00 \mathrm{bD}$ & $2.60 \mathrm{fA}$ & $2.14 \mathrm{gB}$ & $1.76 \mathrm{gBC}$ & $1.32 \mathrm{iCD}$ \\
propamocarb & $1.00 \mathrm{bD}$ & $2.88 \mathrm{efA}$ & $2.32 \mathrm{fgB}$ & $2.18 \mathrm{fgBC}$ & $1.82 \mathrm{fghiC}$ \\
fenamidone + propamocarb & $1.00 \mathrm{bD}$ & $2.52 \mathrm{fA}$ & $2.28 \mathrm{fgB}$ & $2.08 \mathrm{fgBC}$ & $1.70 \mathrm{fghiC}$ \\
fluopicolide + propamocarb & $1.00 \mathrm{bC}$ & $2.96 \mathrm{defA}$ & $2.64 \mathrm{efgA}$ & $2.12 \mathrm{fgB}$ & $2.02 \mathrm{efghB}$ \\
fenamidone & $1.00 \mathrm{bC}$ & $3.32 \mathrm{bcdeA}$ & $3.04 \mathrm{bcdeA}$ & $2.72 \mathrm{cdefAB}$ & $2.20 \mathrm{cdefgB}$ \\
pyraclostrobin + metiram & $1.00 \mathrm{bD}$ & $3.40 \mathrm{bcdeA}$ & $3.00 \mathrm{bcdeAB}$ & $2.60 \mathrm{cdefBC}$ & $2.50 \mathrm{cdeC}$ \\
benthiavalicarb + fluazinam & $1.00 \mathrm{bC}$ & $3.04 \mathrm{defA}$ & $2.50 \mathrm{efgB}$ & $2.38 \mathrm{efgB}$ & $2.12 \mathrm{defghB}$ \\
cymoxanil + mancozeb & $1.00 \mathrm{bC}$ & $3.80 \mathrm{bcA}$ & $3.48 \mathrm{bA}$ & $2.84 \mathrm{cdeB}$ & $2.68 \mathrm{cdB}$ \\
cymoxanil + zoxamide & $1.00 \mathrm{bD}$ & $3.12 \mathrm{defA}$ & $2.73 \mathrm{defgB}$ & $2.45 \mathrm{defBC}$ & $2.14 \mathrm{defgC}$ \\
famoxadone + cymoxanil & $1.00 \mathrm{bD}$ & $3.04 \mathrm{defA}$ & $2.50 \mathrm{efgB}$ & $2.36 \mathrm{efgBC}$ & $2.08 \mathrm{defghC}$ \\
mandipropamid & $1.00 \mathrm{bD}$ & $2.84 \mathrm{efA}$ & $2.32 \mathrm{fgB}$ & $2.16 \mathrm{fgBC}$ & $1.82 \mathrm{fghiC}$ \\
mandipropamid + chlorothalonil & $1.00 \mathrm{bD}$ & $2.66 \mathrm{fA}$ & $2.16 \mathrm{gB}$ & $1.98 \mathrm{fgBC}$ & $1.64 \mathrm{ghiC}$ \\
ametoctradin + metiram & $1.00 \mathrm{bD}$ & $2.83 \mathrm{efA}$ & $2.53 \mathrm{efgB}$ & $2.28 \mathrm{efgBC}$ & $2.03 \mathrm{defghC}$ \\
cyazofamid & $1.00 \mathrm{bD}$ & $3.28 \mathrm{cdeA}$ & $2.58 \mathrm{efgB}$ & $2.35 \mathrm{efgBC}$ & $2.10 \mathrm{defghC}$ \\
fluazinam & $1.00 \mathrm{bC}$ & $3.40 \mathrm{bcdeA}$ & $3.06 \mathrm{bcdeA}$ & $2.56 \mathrm{cdefB}$ & $2.32 \mathrm{cdefB}$ \\
chlorothalonil & $1.08 \mathrm{bD}$ & $3.88 \mathrm{bA}$ & $3.52 \mathrm{bAB}$ & $3.16 \mathrm{cBC}$ & $2.68 \mathrm{cdC}$ \\
mancozeb NT & $1.00 \mathrm{bD}$ & $3.76 \mathrm{bcA}$ & $3.34 \mathrm{bcdAB}$ & $3.08 \mathrm{cdBC}$ & $2.85 \mathrm{cC}$ \\
mancozeb WP & $1.10 \mathrm{bC}$ & $4.84 \mathrm{aA}$ & $4.76 \mathrm{aA}$ & $4.34 \mathrm{bA}$ & $3.84 \mathrm{bB}$ \\
\hline
\end{tabular}

$\mathrm{CV}(\%)=14.52$

*Means followed by lower case letters in the column and upper case letters in the row were not different from each other, as determined by the Tukey's test at $5 \%$ probability.

Source: Elaboration of the authors. 
All tested fungicides showed increased efficacy when the time between application and rain simulation was increased. Results showed that mefenoxam + mancozeb, mefenoxam + chlorothalonil, dimethomorph + ametoctradin, dimethomorph + chlorothalonil, propamocarb, fenamidone + propamocarb, benthiavalicarb + fluazinam, mandipropamid, mandipropamid + chlorothalonil, ametoctradin + metiram, cyazofamid, cymoxanil + zoxamide, and cymoxanil + famoxadone were more effective at controlling potato blight when the precipitation occurred $30 \mathrm{~min}$ after application, while the activity of dimethomorph + mancozeb, fluopicolide + propamocarb, pyraclostrobin + metiram, fluazinam, chlorothalonil, and mancozeb NT was affected up to the 1 HAA interval. The patches treated with fenamidone showed a significant reduction in late blight control up to the 2 HAA interval.

Translaminar or systemic fungicides with inherent tenacity showed greater rainfastness, while contact fungicides were more significantly affected by rain. When rain was simulated 4 HAA, only mefenoxam + mancozeb and mefenoxam + chlorothalonil showed levels of control that were similar to the "no rain" condition.

In experiment 2, all fungicides were equally effective in controlling early blight in the absence of rain, and all were more effective when compared to the control (Table 2 and Figure 2).

Table 2. Severity of early blight (Alternaria solani) in potato plants ('Monalisa') treated with fungicides and subjected to controlled rain $(20 \mathrm{~mm})$ at $30 \mathrm{~min}, 1,2$, and $4 \mathrm{~h}$ after application.

\begin{tabular}{lcllll}
\hline \multirow{2}{*}{ Treatment } & \multicolumn{5}{c}{ Time interval for subjecting plants to controlled rain after fungicide application } \\
\cline { 2 - 6 } & No rain & $30 \mathrm{~min}$ & $1 \mathrm{~h}$ & $2 \mathrm{~h}$ & $4 \mathrm{~h}$ \\
\hline picoxystrobin & $1.00 \mathrm{bC}$ & $3.10 \mathrm{efA}$ & $2.48 \mathrm{efB}$ & $1.92 \mathrm{gB}$ & $1.20 \mathrm{hiC}$ \\
azoxystrobin & $1.00 \mathrm{bD}$ & $3.52 \mathrm{cdeA}$ & $3.26 \mathrm{cdeA}$ & $2.28 \mathrm{defgB}$ & $1.68 \mathrm{efghiC}$ \\
pyraclostrobin + metiram & $1.00 \mathrm{bD}$ & $3.72 \mathrm{cdeA}$ & $3.44 \mathrm{cdA}$ & $2.86 \mathrm{cdeB}$ & $2.36 \mathrm{cdC}$ \\
azoxystrobin + difenoconazole & $1.00 \mathrm{bC}$ & $2.85 \mathrm{fA}$ & $2.28 \mathrm{fB}$ & $1.86 \mathrm{gB}$ & $1.12 \mathrm{iC}$ \\
pyraclostrobin + metconazole & $1.00 \mathrm{bC}$ & $3.20 \mathrm{defA}$ & $2.58 \mathrm{efB}$ & $2.24 \mathrm{efgB}$ & $1.14 \mathrm{iC}$ \\
trifloxystrobin + tebuconazole & $1.00 \mathrm{bD}$ & $3.12 \mathrm{efA}$ & $2.60 \mathrm{fB}$ & $2.00 \mathrm{gC}$ & $1.08 \mathrm{iD}$ \\
tebuconazole & $1.00 \mathrm{bE}$ & $3.28 \mathrm{defA}$ & $2.58 \mathrm{fB}$ & $2.06 \mathrm{gC}$ & $1.48 \mathrm{efghiD}$ \\
metconazole & $1.00 \mathrm{bC}$ & $3.10 \mathrm{efA}$ & $2.36 \mathrm{fB}$ & $2.14 \mathrm{fgB}$ & $1.38 \mathrm{fghiC}$ \\
difenoconazole & $1.00 \mathrm{bC}$ & $3.06 \mathrm{fA}$ & $2.48 \mathrm{fB}$ & $2.16 \mathrm{fgB}$ & $1.28 \mathrm{ghiC}$ \\
boscalid & $1.00 \mathrm{bC}$ & $3.32 \mathrm{cdefA}$ & $2.52 \mathrm{fB}$ & $2.26 \mathrm{defgB}$ & $1.40 \mathrm{efghiC}$ \\
boscalid + pyraclostrobin & $1.00 \mathrm{bD}$ & $2.96 \mathrm{fA}$ & $2.48 \mathrm{fB}$ & $1.96 \mathrm{gC}$ & $1.44 \mathrm{efghiD}$ \\
cyprodinil & $1.00 \mathrm{bD}$ & $3.02 \mathrm{fA}$ & $2.66 \mathrm{efB}$ & $2.20 \mathrm{fgB}$ & $1.52 \mathrm{efghiC}$ \\
pyrimethanil & $1.00 \mathrm{bD}$ & $3.18 \mathrm{defA}$ & $2.76 \mathrm{efAB}$ & $2.36 \mathrm{defgB}$ & $1.82 \mathrm{defghC}$ \\
pyrimethanil + iprodione & $1.00 \mathrm{bC}$ & $3.05 \mathrm{fA}$ & $2.60 \mathrm{fA}$ & $2.06 \mathrm{gB}$ & $1.70 \mathrm{efghiB}$ \\
famoxadone + mancozeb & $1.00 \mathrm{bD}$ & $3.06 \mathrm{fA}$ & $2.70 \mathrm{efAB}$ & $2.28 \mathrm{defgBC}$ & $1.74 \mathrm{efghiC}$ \\
fluazinam & $1.00 \mathrm{bD}$ & $3.28 \mathrm{defA}$ & $2.84 \mathrm{defAB}$ & $2.44 \mathrm{defgB}$ & $1.92 \mathrm{defC}$ \\
iprodione & $1.00 \mathrm{bD}$ & $3.70 \mathrm{cdeA}$ & $3.26 \mathrm{cdeA}$ & $2.72 \mathrm{defB}$ & $2,02 \mathrm{deC}$ \\
chlorothalonil & $1.04 \mathrm{bD}$ & $3.76 \mathrm{cdA}$ & $3.42 \mathrm{cdA}$ & $2.88 \mathrm{cdB}$ & $2.40 \mathrm{cdC}$ \\
mancozeb NT & $1.00 \mathrm{bD}$ & $3.94 \mathrm{cA}$ & $3.60 \mathrm{cAB}$ & $3.36 \mathrm{cB}$ & $2.82 \mathrm{cC}$ \\
mancozeb WP & $1.10 \mathrm{bC}$ & $5.08 \mathrm{bA}$ & $4.78 \mathrm{bA}$ & $4.64 \mathrm{bA}$ & $4.14 \mathrm{bB}$ \\
control & $5.86 \mathrm{aA}$ & $5.82 \mathrm{aA}$ & $5.96 \mathrm{aA}$ & $5.92 \mathrm{aA}$ & $6.00 \mathrm{aA}$ \\
\hline CV & & & & & \\
\hline
\end{tabular}

CV (\%) 14.23

* Means followed by lower case letters in the column and upper case letters in the row were not different from each other, as determined by the Tukey's test at 5\% probability.

Source: Elaboration of the authors. 
When rain was simulated $30 \mathrm{~min}$ and 1 HAA, the fungicides azoxystrobin + difenoconazole, pyraclostrobin + metconazole, boscalid + pyraclostrobin, trifloxystrobin + tebuconazole, picoxystrobin, boscalid, tebuconazole, metconazole, difenoconazole, cyprodinil, iprodione pyrimethanil, pyrimethanil, famoxadone + mancozeb, and fluazinam were the most effective in control of early blight. The fungicides azoxystrobin, pyraclostrobin + metiram, iprodione, mancozeb NT, and chlorothalonil showed intermediate efficacy, whereas mancozeb WP was the least effective.

When rain was simulated 2 and $4 \mathrm{HAA}$, the control levels were similar to those observed at $30 \mathrm{~min}$ and $1 \mathrm{~h}$ intervals. The patches treated with azoxystrobin showed significantly better control of early blight, being as effective as the best treatment, at the earlier intervals.

Figure 2. Severity of early blight (Alternaria solani) in potato plants ('Monalisa') treated with fungicides with and without exposure to simulated rain $(20 \mathrm{~mm})$ at $30 \mathrm{~min}, 1,2$, and $4 \mathrm{~h}$ after application.

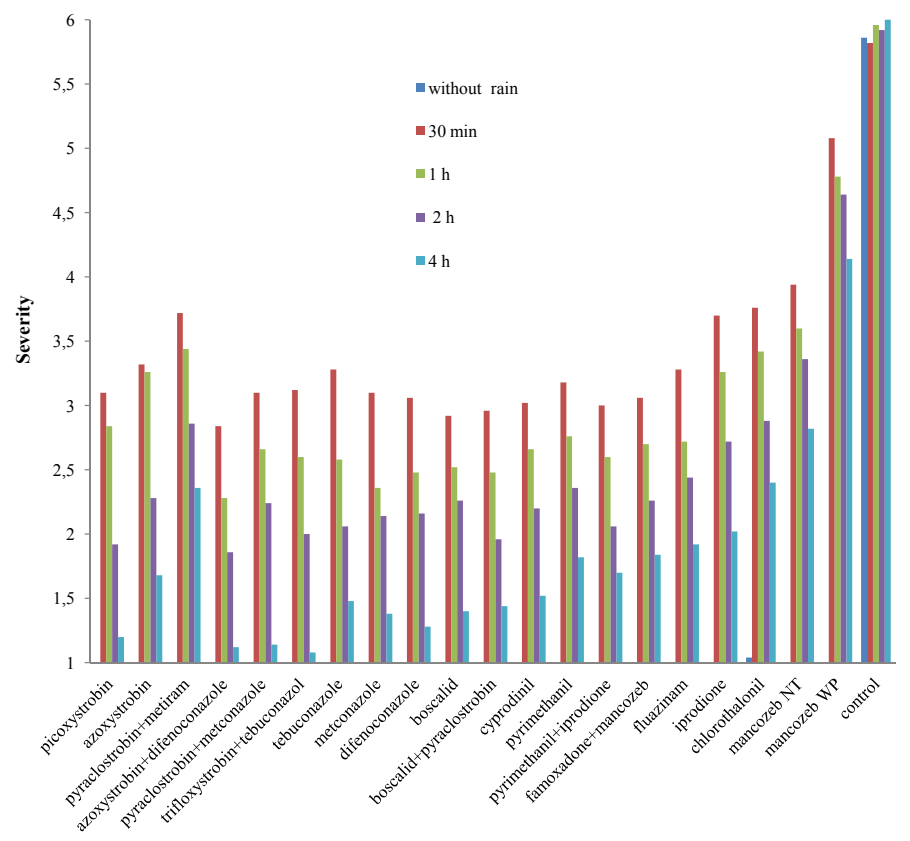

Source: Elaboration of the authors.

Plantstreated withazoxystrobin + difenoconazole, pyraclostrobin + metconazole, trifloxystrobin + tebuconazole, tebuconazole, metconazole, difenoconazole, boscalid + pyraclostrobin, picoxystrobin, boscalid, and cyprodinil were more affected when the precipitation occurred $30 \mathrm{~min}$ after fungicide application, while those treated with fluazinam, azoxystrobin, pyraclostrobin + metiram, pyrimethanil, iprodione + pyrimethanil, famoxadone + mancozeb, iprodione, mancozeb NT, and chlorothalonil were affected at the 1 HAA interval. Mancozeb was the fungicide most significantly affected by simulated rain, showing increased control of early blight only at the 4 HAA interval.

The fungicides picoxystrobin, azoxystrobin + difenoconazole, pyraclostrobin + metconazole, trifloxystrobin + tebuconazole, difenoconazole, metconazole, boscalid, and boscalid + pyraclostrobin showed similar control levels to those of the "no rain" condition, at the interval of 4 HAA.

Simulated rain had a significant effect on the efficacy of fungicides tested for use in the control of late and early blight of potato. Systemic or translaminar fungicides, or those with recognized 
tenacity, showed greater rainfastness than contact fungicides.

More effective control of late and early blight was observed when rain was simulated $30 \mathrm{~min}$ and 1 HAA of translaminar or systemic fungicides, or those with inherent tenacity. The efficacy wettable powder (WP) formulation of mancozeb was affected at all tested intervals.

Collectively, the results showed that the efficacy of fungicides increased as the time between pulverization and rain simulation increased. These results indicate that longer periods between application and precipitation lead to increased chances of drying and adherence of the deposits to the treated leaf surface, or to higher penetration or translocation of the product through the plant (BRUGGEN et al., 1987; SCHEPERS, 1996; DUARTE, 2008; OLIVEIRA, 2009).

Systemicity and tenacity played an important role on the rainfastness of the fungicides. The best results were obtained following the application of systemic fungicides, followed by translaminar fungicides and those with inherent tenacity. The efficacy of translaminar fungicides varied, depending on their isolated use or the characteristics of the combined treatment used. When isolated or combined with low tenacity fungicides, these products were less resistant to rain in relation to mixtures containing fungicides with recognized tenacity. The efficacy of contact fungicides varied according to their capacity to adhere to the treated surface. The tenacity of cyazofamid, fluazinam, ametoctradin, famoxadone, and chlorothalonil determined the rainfastness of these fungicides and their ability to control late blight under critical conditions, a fact that was not observed for mancozeb WP.

The fungicide mefenoxam, in combination with mancozeb or chlorothalonil, showed the greatest rainfastness, representing the only product recommended to control late blight, with control levels at the 4 HAA interval similar to those at the "no rain" condition. This can be explained by the excellent systemic features of mefenoxam (COHEN; COFFEY, 1986; BRUGGEN et al., 1987; SINGH; PUNDHIR, 2004; MULLER; GISI, 2007).

The positive effects of fluopicolide + propamocarb and fenamidone + propamocarb were consistent with those observed by Tafforeau et al. (2009). According to these authors, the two mixtures, under critical periods of rain, were more effective in the control of late blight when compared to cyazofamid, dimethomorph + mancozeb, and zoxamide + mancozeb. The rainfastness of fluopicolide + propamocarb and fenamidone + propamocarb can be explained by the significant translaminar effect of fluopicolide, and systemic effect of propamocarb (JOHNSON; CUMMINGS; GEARY, 2000; TAFFOREAU et al., 2006).

The rainfastness of mandipropamid can be explained by its ability to adhere to the existing wax coating on the leaf surface (HERMANN et al., 2005; HUGGENBERGER; KNAUF-BEITER, 2007). The higher efficacy of mandipropamid when compared to mancozeb and dimethomorph + mancozeb, as found in experiment 1, was also observed by Kappes and Huggenberger (2007).

The rainfastness of benthiavalicarb + fluazinam can be explained by the substantial tenacity observed for both fungicides (MIYAKE et al., 2005; WHITTINGHAN, 2007; SCHEPERS, 1996; KOMYOJI et al., 1995).

Despite the limited translaminar effect of dimethomorph (COHEN; BALDER; COHEN, 1995), this fungicide showed good rainfastness when combined with chlorothalonil or ametoctradin. However, this was not observed when dimethomorph was used in combination with mancozeb, which may be attributed to the higher tenacity of chlorothalonil and ametoctradin, compared to mancozeb (SUEHI; LATIN, 1991; GOLD et al., 2009; REIMANN et al., 2010a). The similar rainfastness observed for dimethomorph + ametoctradin, ametoctradin + metiram, mandipropamid, and cyazofamid in the present study are consistent with the results obtained by Reimann et al. (2010b). 
Likewise, the results obtained for cymoxanil + famoxadone and cymoxanil + zoxamide, relating to their rainfastness, can be explained by the translaminar effect of cymoxanil in the tissues (COHEN; COFFEY, 1986) and the high tenacity shown by famoxadone (ANDRIEU et al., 2001) and zoxamide (BRADSHAW; SCHEPERS, 2001). The mixture of cymoxanil + mancozeb had an intermediate effect due to the low tenacity of mancozeb (SUEHI; LATIN, 1991, TÖFOLI et al., 2006).

Although cyazofamid is considered a contact fungicide, it demonstrated resistance to simulated rain with similar control levels against potato blight as observed for the mobile fungicides. The tenacity of this fungicide is due to its high ability to adhere to the layer of wax present on the surface of the leaves (EBERSOLD, 2002; BODKER; NIELSEN, 2002; SAUTER, 2007).

The fungicides pyraclostrobin + metiram showed intermediate levels of control of late and early blight in potato plants exposed to simulated rain. The limited translaminar effect of pyraclostrobin and the low tenacity of metiram, respectively, make the deposits of this mixture more vulnerable to the effect of rain (BARTLETT, 2002; TÖFOLI, 2006).

The limited rainfastness of fenamidone, observed in this study, was also documented by Bodker and Nielsen (2002). They found that fenamidone + mancozeb demonstrated less rainfastness than cyazofamid, zoxamide + mancozeb, dimethomorph + mancozeb, and fluazinam. This limited rainfastness may be attributed to its low systemicity and, consequently, greater exposure to external factors (SAUTER, 2007).

In terms of controlling early blight, treatment with picoxystrobin, azoxystrobin + difenoconazole, pyraclostrobin + metconazole, trifloxystrobin + tebuconazole, metconazole, difenoconazole, boscalid, or boscalid + pyraclostrobin showed greater rainfastness, promoting control levels at the 4 HAA interval, which were similar to those observed for the "no rain" condition. This result may be explained by the different levels of mobility and/ or adherence to the leaf surface by these fungicides (KUCK; VORS, 2007; BARTLETT et al., 2002).

The high resistance of strobilurins mixed with triazoles, and triazoles alone to precipitation, is related to the marked systemicity of triazoles, since strobilurins show variable levels of translaminar effect (FORCELINI, 1994; BARTLETT et al., 2002). Debortoli (2008) also observed a lower impact of simulated rain on the control of soybean rust in a few soybean cultivars treated with azoxystrobin + cyproconazole, picoxystrobin + epoxiconazole, picoxystrobin + cyproconazole, and tebuconazole.

The increasing control of early blight provided by azoxystrobin as the time between application and rain simulation increased, may be explained by its substantial systemic activity (BARTLETT et al., 2002; TÖFOLI et al., 2002; SAUTER, 2007). It is likely that a longer period between fungicide application and rain simulation allowed for higher absorption and adherence of the product, making it less susceptible to wash-off at the 2 and 4 HAA intervals.

Although picoxystrobin was similar to azoxystrobin and pyraclostrobin in terms of controlling early blight at the different intervals of simulated rain, only picoxystrobin provided control at 4 HAA, which was similar to that achieved under the "no rain" condition. This result can be explained by the greater systemicity of picoxystrobin, when compared to the other strobilurins (BARTLETT et al., 2002).

The greater rainfastness of azoxystrobin + difenoconazole when compared to azoxystrobin alone, observed at the $30 \mathrm{~min}$ and $1 \mathrm{~h}$ interval, can be attributed to the complementary systemic activity of difenoconazole. The greater rainfastness of difenoconazole over azoxystrobin observed in this study suggests that difenoconazole presents a broader systemicity when compared to azoxystrobin. Likewise, the combination of 
pyraclostrobin + metconazole was more effective than pyraclostrobin + metiram due to the greater systemicity of metconazole (FORCELINI, 1994; KUCK; VORS, 2007).

The reduced control of early blight following application of the fungicides iprodione and boscalid after exposure to simulated rain was also noted by Pigati, Dernoeden, and Grybauskas (2010) while studying the control of Sclerotinia homeocarpa on golf courses. In experiment 2, the greater rainfastness observed for boscalid, when compared to iprodione, may be explained by its greater systemicity in relation to this dicarboximid (HEWIT, 1998; RHEINHEIMER, 2007).

The greater rainfastness demonstrated by the combination of pyrimethanil + iprodione and cyprodinil may be attributed to the systemicity of these two anilinopyrimidines (GISI; MULLER, 2007).

The rainfastness of fluazinam and its ability to control late and early blight of potato observed in this study is due to its known inherent tenacity (WHITTINGHAM, 2007). This characteristic was also described by Schepers (1996), whose results showed that fluazinam was less affected than maneb after exposure to $10 \mathrm{~mm}$ of rain at 4 HAA. This study also showed that, under certain circumstances, rain led to an increase in the efficacy of fluazinam, likely due to a redistribution of the product over the treated surface. This was however not observed in the present study.

Owing to the greater tenacity of chlorothalonil and mancozeb NT, these classic contact fungicides are more effective than mancozeb WP (SUEHI; LATIN, 1991; TÖFOLI et al., 2006). Of all the fungicides tested, mancozeb WP, was most significantly affected by simulated rain. In this case, effective control of late and early blight was only observed when the rain occurred at 4 HAA; however, the control level was poorer than that observed in the "no rain" condition. According to Duarte (2008), a drying period of at least $6 \mathrm{~h}$ is necessary to retain mancozeb in tomato and potato plants. This explains the findings obtained in this study, in which the longest interval between application and rain simulation was $4 \mathrm{~h}$.

In the present study, there was significant variability between mancozeb formulations. The higher efficacy of the NT formulation over the WP can be explained by the fact that the NT particles are smaller, thus allowing a greater adhesion to the treated surface and providing better control of late and early blight of potato under adverse conditions (TÖFOLI et al., 2006).

Finally, it is important to highlight that other positive characteristics also support the rainfastness demonstrated in this study by systemic and translaminar fungicides and by those with inherent tenacity. These include protective, residual, curative, and antisporulant effects that increase the efficacy of these products, thereby making them a better option for use in integrated management programs of late and early potato blight (HEWIT, 1998; SHILDER, 2010; TÖFOLI; MELO; DOMINGUES, 2012; TÖFOLI et al., 2013).

\section{Conclusions}

Systemic and translaminar fungicides, and those with inherent tenacity, were the least affected by simulated rain when compared to contact fungicides. The increase in drying time had a direct effect on the control of late and early blight, due to greater retention or absorption of the tested products.

The identification of unstable periods, associated with the prospect of rain and the presence of disease in the field, suggests a need to opt for fungicides that show higher efficacy under critical conditions. 


\section{References}

ANDRIEU, N.; JAWORSKA, G.; GENET J.; BOMPEIX, G. Biological mode of action of famoxadone on Plasmopara viticola and Phytophthora infestans. Crop Protection, Guildford, v. 20, n. 3, p. 253-260, 2001.

BARTLETT, D. W.; J. M.; CLOUGH, J. R.; GODWIN, A. A.; HALL, M.; HAMER, M.; PARR-DOBRZANSKI, B. Review: the strobilurin fungicides. Pest Management Science, West Sussex, v. 58, n. 7, p. 649-662, 2002.

BODKER, L.; NIELSEN, B. J. Influence of irrigation on the wash-off of fungicides in field grown potato. $P P O-$ Special Report, Edingburgh, 2002. v. 8, p. 163-167.

BRADSHAW, N. J.; SCHEPERS, H. T. A. M. Experiences with RH-117281 (zoxamide) - a new fungicide for the control of potato blight. PPV-Special Report, Munich, $\mathrm{n}$. 7, p. 173-183, 2001.

BRUGGEN, A. H. C.; MILGROOM, M. G.; OSMELOSKI, J. F.; FRY, W. E.; JACOBSON, J. S. Attenuation of metalaxyl on potato leaves by simulated acidic rain and residence time. Phytopathology, St. Paul, v. 77, n. 5, p. 401-406, 1987.

CABRAS, P.; ANGIONI, A.; GARAU, V. L; MELIS, M.; PIRISI, F. M.; CABITZA, F.; PALA, M. The effect of simulated rain on folpet and mancozeb residues on grapes and wine leaves. Journal of Environmental Science and Health, New York, v. 36, n. 5, p. 609-618, 2001.

COHEN, Y.; BALDER, A.; COHEN, B. H. Dimetomorph activity against oomycete fungal plant pathogens. Phytopathology, St Paul, v. 85, n. 12, p. 1500-1506, 1995.

COHEN, Y;; COFFEY, M. D. Systemic fungicides and the control of oomycetes. Annual Review Phytopathology, Palo Alto, v. 24, n. 24, p. 311-338, 1986.

DEBORTOLI, M. P. Efeito do "Rainfastness" e adjuvante na aplicação de fungicidas foliares em cultivares de soja. 2008. Dissertação (Mestrado em Engenharia Agrícola) Universidade de Santa Maria, Santa Maria.

DIAS, J. A. C.; IAMAUTI, M. T. Doenças da batateira (Solanum tuberosum). In: KIMATI, H.; AMORIN, L.; REZENDE, J. A. M.; BERGAMIN FILHO, A.; CAMARGO, L. E. A. (Ed.). Manual de fipatologia: doenças das plantas cultivadas. 4. ed. São Paulo: Ceres, 2005. v. 2, p. 119-142.

DUARTE, A. R. Remoção de resíduos de fungicidas por meio de chuva simulada e irrigação em batateira e tomateiro. 2008. Dissertação (Mestrado em Fitopatologia) - Universidade Federal de Viçosa, Viçosa.
EBERSOLD, D. Ranman, the new marathon fungicide. PPO-Special Report, Edinburgh, 2002. v. 8, p. 225-230.

EVENHUIS, A.; SCHEPERS, H. T. A. M; BUS, C. B.; STEGEMAN, W. L. M. Rainfastness of mancozeb and Curzate M on potato leaves. PAV-Special Report, Carlow, v. 3, p. 218-225, 1998.

FIFE, J. P.; NOKES, S. E. Evaluation of the effect of rainfall intensity and duration on the persistence of chlorothalonil on processing tomato foliage. Crop Protection, Guildford, v. 21, n. 9, p. 733-740, 2002.

FORCELINI, C. A. Fungicidas inibidores da síntese de esteróis. I Triazoles. Revisão Anual de Patologia de Plantas, Passo Fundo, 1994. v. 2, p. 335-355.

GISI, U.; MÜLLER, U. Anilinopyrimidines: methionine biosynthesis inhibitors. In: KRÄMER, W.; SCHIRMER, U. (Ed.). Modern crop protection compounds. Berlin: Verlag, 2007. v. 2, p. 551-560.

GOLD, R.; SCHERER, M.; RETHER J.; SPEAKMAN J.; NAVÉ, B.; LEVY, T.; STORER, R.; MARRIS, D.

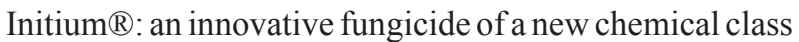
for the control of oomycetes. In: BCPC CONGRESS, 2009, Glasgow. Proceedings... Glasgow: BCPC, 2009. p. 1-6.

GREEN, J. M. Factors that influence adjuvant performance. In: INTERNATIONAL SYMPOSIUM ON ADJUVANTS FOR AGROCHEMICALS, 6., 2001, Amsterdam. Proceedings... Amsterdam: ISAA Foundation, 2001. p. 179-190.

HERMANN, D.; BARLETT, D. W.; FISCHER, W.; KEMPF, H. J. The behavior of mandipropamid in plants. In: BCPC CROP SCIENCE \& TECHONOLOGY, 2005, Glasgow. Proccedings... Glasgow: BCPC, 2005. p. 9398.

HEWIT, H. G. Fungicides in crop protection. New York: CAB International, 1998. 221 p.

HUGGENBERGER, F.; KNAUF-BEITER, G. Mandipropamid a new fungicides for the control of late blight in potatoes. PPO-Special Report, Bologna, v. 12, p. 67-76, 2007.

HUNSCHE, M.; DAMEROW, L.; SCHMITZEIBERGER, M.; NOGA, G. Mancozeb wash-off from apple seedlings by simulated rainfall as affected by drying time of fungicide deposit and rain characteristics. Crop Protection, Bonn, v. 26, n. 5, p. 768-774, 2007.

JOHNSON, D. A.; CUMMINGS, T. F.; GEARY, B. Postinfection activity of selected late blight fungicides. Plant Disease, St. Paul, v. 84, n. 10, p. 1116-1120, 2000. 
KAPPES, E. M.; HUGGENBERGER, F. Revus: field performance and product recommendations against late blight in potatoes in Europe. PPO-Special report, Bologna, 2007. v. 12, p. 121-128.

KOMYOJI, T.; SUGIMOTO, K.; MITANI, S.; MATSUO, N.; KAZUMI, S. Biological properties of a new fungicide, fluazinam. Journal Pesticide Science, Tokyo, v. 20, n. 2, p. 129-135, 1995.

KUCK, K. H.; VORS, J. P. Sterol biosynthesis inhibitors. In: KRÄMER, W.; SCHIRMER, U. (Ed.). Modern crop protection compounds. Berlin: Verlag, 2007. v. 2, p. 605650.

KUDSK, P.; MATHIASSEN, S. K.; KIRKNEL, E. Influence of formulations and adjuvants on the rainfastness of maneb and mancozeb on pea and potato. Pesticide Science, London, v. 33, n. 1, p. 57-71, 1991.

MIYAKE, Y.; SAKAI, J.; SHIBATA, M.; YONEKURA, N.; MIURA, I.; KUMAKURA, K.; NAGAYAMA, K. Fungicidal activity of Benthiavalicarb-isopropyl against Phytophthora infestans and its controlling activity against late blight diseases. Journal Pesticide Science, Tokyo, v. 30, n. 4, p. 390-396, 2005.

MULLER, U.; GISI, U. Newest aspects of nucleic acid synthesis inhibitors: Metalaxyl-M. In: KRÄMER, W.; SCHIRMER, U. (Ed.). Modern crop protection compounds. Berlin, v. 2, p. 739-746, 2007.

OLIVEIRA, S. H. F.; SANTOS, J. M. F.; GUZZO, S. D. Efeito da chuva sobre a tenacidade e eficiência de fungicidas cúpricos associados ao óleo vegetal no controle da ferrugem do cafeeiro. Fitopatologia Brasileira, Brasília, v. 27, n. 6, p. 581-585, 2002.

OLIVEIRA, M. A.P. Remoção pela chuva de diferentes formulações de flutriafol aplicada em soja, com e sem a adição de óleo mineral na calda. 2009. Tese (Doutorado em Agronomia — Energia na Agricultura) - Universidade Estadual Paulista "Júlio de Mesquita Filho", Botucatu.

PIGATI, R. L.; DERNOEDEN, P. H.; GRYBAUSKAS, A. P. Simulated rainfall and mowing impact fungicide performance when targeting dollar spot in creeping bentgrass. Plant Disease, St. Paul, v. 94, n. 5, p. 596-603, 2010 .

REIMANN, S.; JILDERDA, K.; GERBER, M.; TEGGE, V.; KLAPPACH, K. Initium $®$ : a new fungicidal active ingredient for the control of Oomycetes. PPO-Special Report, Arras, v. 14, p. 89-94. 2010a.

Initium ${ }^{\circledR}$ based products for the control of Phytophthora infestans in potatoes. PPO-Special Report, Arras, v. 14, p. 95-100, 2010b.
REYNOLDS, K. L.; REILLY, C. C.; HOTCHKISS, M. W. Removal of fentin hydroxide from pecan seedlings by simulated rain. Plant Disease, St Paul, v. 78, n. 9, p. 857-860, 1994.

RHEINHEIMER, J. Succinate dehydrogenase inhibitors. In: KRÄMER, W.; SCHIRMER, U. (Ed.). Modern crop protection compounds. Berlin: Verlag, 2007. v. 2, p. 496504.

RICH, S. Dynamics of deposition and tenacity of fungicides. Phytopathology, St Paul, v. 44, n. 3, p. 203213, 1954.

SANTOS, J. M. F. Protótipo experimental de torre móvel para simulação de chuva controlada e pulverização a diferentes volumes. Fitopatologia Brasileira, Brasília, v. 25, p. 345, 2000. Suplemento.

SANTOS, J. M. F.; OLIVEIRA, S. H. F.; DOMINGUES, R. J.; GUZZO, S. D. Avaliação da eficácia de fungicidas sistêmicos no controle da ferrugem (Hemileia vastatrix) do cafeeiro, sob chuva simulada. Arquivos do Instituto Biológico, São Paulo, v. 69, n. 1, p. 45-49, jan./mar. 2002.

SAUTER, H. Strobilurins and other complex. III. Inhibitors. In: KRÄMER, W.; SCHIRMER, U. (Ed.). Modern crop protection compounds. Berlin: Verlag, 2007. v. 2, p. 457-495.

SCHEPERS, H. T. A. M. Effect of rain on efficacy of fungicide deposits on potato against Phytophthora infestans. Potato Research, Washington, v. 39, n. 4, p. 541-550, 1996.

SCHEPERS, H. T. A. M.; NIELSEN, B. J.; DUVAUCHELLE, S. Harmonized protocol for evaluation of rainfastness of late blight fungicides. $P P O-$ Special Report, Jersey, v. 10, p. 161-163, 2004.

SCHILDER, A. Fungicides properties and weather conditions. Plant \& Pest Advisory, New Jersey, v. 15, n. 12, p. 1-3, 2010.

SINGH, R. P.; PUNDHIR, V. S. Uptake, translocation and persistence of metalaxyl in potato. Journal of Mycology and Plant Pathology, Udaipur, v. 34, n. 1, p. 93-95, 2004.

STEVENSON, W.; KIRK, W.; ATALLAH, Z. K. Managing foliar disease: early blight, late blight and white mold. In: JOHNSON, D. A. (Ed.). Potato health management. St. Paul: APS, 2008. p. 209-222.

SUEHI, B.; LATIN, C. Retention of fungicides for control of alternaria leaf spot of muskmelon under greenhouse conditions. Plant Disease, St. Paul, v. 75, n. 10, p. 1013$1015,1991$. 
TAFFOREAU, S.; BARDSLEY, E.; LATORSE, M. P.; FABRĖGES, C.; SCHIRRINGS, A.; WEGMANN, T. Infinito: Profile of a novel potato late blight fungicides. Summary of three years of development trials in Europe. PPO-Special Report, Tallinn, v. 11, p. 77-88, 2006.

TAFFOREAU, S.; LATORSE, M. P.; JUHL, O.; BARDSLEY, E. Consento: new experiences on the control of late blight 2007-2008. A summary of recent data with Consento in Europe. PPO-Special Report, Hamar, v. 13, p. 135-142, 2009.

THACKER, J. R. M.; YOUNG, R. D. F. The effects of six adjuvants on the rainfastness of chlorpyrifos formulated as an emulsifinable concentrate. Pesticide Science, London, v. 55, n. 3, p. 198-200, 1999.

TÖFOLI, J. G.; MELO, P. C. T.; DOMINGUES, R. J.; FERRARI, J. T. Controle da requeima e pinta preta da batata por fungicidas: conceitos, evolução e uso integrado. Biológico, São Paulo, v. 75, n. 1, p. 41-52, 2013.

TÖFOLI, J. G.; MELO, P. C. T.; DOMINGUES, R. J. Ação protetora, residual, curativa e anti-esporulante de fungicidas no controle da requeima e da pinta preta da batata em condições controladas. Arquivos do Instituto Biológico, São Paulo, v. 79, n. 2, p. 209-221, 2012.
TÖFOLI, J. G.; DOMINGUES, R. J.; FERRARI, J. T.; NOGUEIRA, E. M. C. Doenças fúngicas da cultura da batata: sintomas, etiologia e manejo. Biológico, São Paulo, v. 74, n. 1, p. 63-73, 2012.

TÖFOLI, J. G.; DOMINGUES, R. J.; SANTOS, J. M. F.; LOURENZONI JÚNIOR, A. M. Efeito de chuva simulada sobre a eficácia de Dithane NT (mancozebe) no controle da requeima do tomateiro. Biológico, São Paulo, v.68, Suplemento, p.604-606, 2006. Suplemento.

TÖFOLI, J. G.; OLIVEIRA, S. H. F.; DOMINGUES, R. J.; SANTOS, J. M. F.; MARTINS, E. M. F. Desempenho de azoxystrobin no controle da ferrugem do cafeeiro sob condições de chuva induzida. Arquivos do Instituto Biológico, São Paulo, v. 69, n. 1, p. 93-96, 2002.

WHITTINGHAM, W. G. Uncouplers of oxidative phosforylation. In: KRÄMER, W.; SCHIRMER, U. (Ed.). Modern crop protection compounds. Berlin: Verlag, v. 2, p. 505-527, 2007. 
